\title{
Bibliometric analysis of publications by South African viticulture and oenology research centres
}

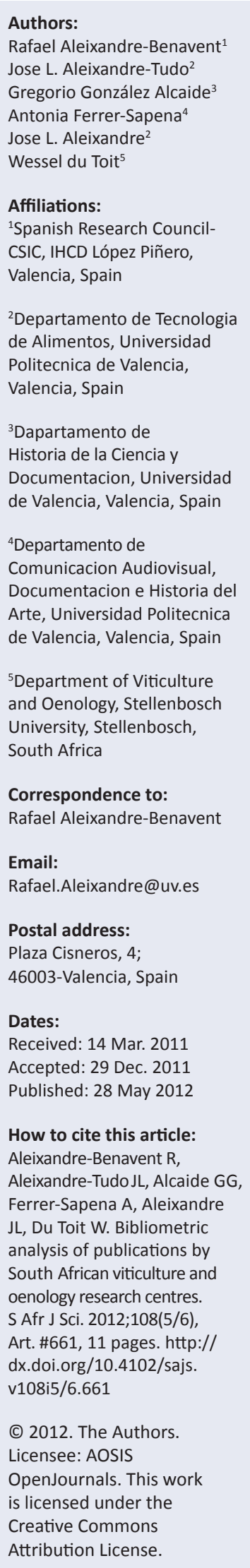

\section{Authors:}

Antonia Ferrer-Sapena ${ }^{4}$

Jose L. Aleixandre ${ }^{2}$

Affiliations:

${ }^{1}$ Spanish Research CouncilCSIC, IHCD López Piñero,

Valencia, Spain

2Departamento de Tecnologia

Politecnica de Valencia,

${ }^{3}$ Dapartamento de

Historia de la Ciencia y

Documentacion, Universidad

${ }^{4}$ Departamento de

Comunicacion Audiovisual, Documentacion e Historia de Arte, Universidad Politecnica Valencia, Valencia, Spain and Oenology, Stellenbosch University, Stellenbosch,

Correspondence to: Rafael Aleixandre-Benavent

Email:

Postal address:

Plaza Cisneros, 4;

-Valencia, Spain

Accepted: 29 Dec. 2011

Published: 28 May 2012

Aleixandre-Benavent $\mathrm{R}$

Ferrer-Sapena A, Aleixandre

JL, Du Toit W. Bibliometric lysis of publications by South African viticulture and

Art. \#661, 11 pages. http://

dx.doi.org/10.4102/sajs.

C 2012. The Authors

Licensee: AOSIS

OpenJournals. This work

Creative Commons
We analysed the production, impact factor of, and scientific collaboration involved in viticulture and oenology articles associated with South African research centres published in international journals during the period 1990-2009. The articles under scrutiny were obtained from the Science Citation Index database, accessed via the Web of Knowledge platform. The search strategy employed specific viticulture and oenology terms and was restricted to the field 'topic'. The results showed that 406 articles were published during the review period, with the most number of publications being in the South African Journal of Enology and Viticulture $(n=34)$, American Journal of Enology and Viticulture $(n=16)$ and Journal of Agricultural and Food Chemistry $(n=16)$. The articles were published by 851 authors from 236 institutions. The collaboration rate was 3.7 authors per article, having grown over the two decades examined. The most productive institutions (i.e. those receiving a greater number of citations) were Stellenbosch University (219 published articles and 2592 citations) and the Agricultural Research Council (49 published articles and 454 citations), both from South Africa. Graphical representation of co-authorship networks identified 18 groups of authors and a single network of institutions whose core is Stellenbosch University. In conclusion, we have identified a significant growth in South African viticulture and oenology research in recent years, with a high degree of internationalisation and a constant level of domestic collaboration.

\section{Introduction}

The cultivation area of vineyards in South Africa is located in a narrow belt of Mediterranean climate on the slopes of mountains and valleys in the Western Cape Province. Good soil and climatic conditions have made it possible for nearly 4500 grape growers to cultivate 106000 hectares of vineyards in this region. There were 493 private wineries and a total of 573 cellars in 2011. Although production was previously dominated by white wines, there is now a tendency towards a greater balance between the production of white and red wines, as well as distillates. These tendencies have also led to an increased interest in the treatment of wastewater from this growing wine industry. $1,2,3,4,5$

South Africa is one of the most prolific New World wine producing countries. With an annual output of 600 million litres, it is the ninth largest producer of wine in the world. Exports constitute about one quarter of this production, but an increase in international sales has been observed over the last decade. ${ }^{6}$ The increasing importance of the South African wine industry in both the domestic and international markets has been accompanied by an increase in research activities in wine-related subject areas. In addition to studies carried out on different grapevine diseases, $, 7,9,10$ efforts to geographically characterise wine and spirits regions, as well as the development of indigenous varieties and alcoholic beverages are increasing. ${ }^{11,12,13,14}$ Thus far, there has been no comprehensive analysis of wine-related research such as has been carried out in other areas of scientific activity in South Africa, for example, Medicine, ${ }^{15}$ Bioinformatics, ${ }^{16}$ Engineering ${ }^{17}$, and HIV and AIDS. ${ }^{18}$ Trends and implications of South Africa's scientific outputs have also recently been studied. ${ }^{19}$

Articles published in scientific journals are one of the measurable outcomes of research activity, and may be analysed by qualitative and quantitative methods. The qualitative 'peer review', based on expert opinion is an indispensable basic condition imposed by editors before research will be published in prestigious journals. The quantitative determination is based on a series of measures or indicators that are derived from statistical analysis of published scientific literature and included in bibliographic databases. ${ }^{20,21,22}$ These indicators measure the scientific activity of researchers and their institutions, given that they determine the articles that have been published, their literature characteristics as well as establishing collaborative relationships with each other. Authors can extend credit to colleagues' publications by quoting them so that the citation counts reflect the impact that published articles have had on previous publications and their authors. ${ }^{23,24}$ 
Scientific collaboration facilitates the flow of information amongst researchers in order to share costs and improve efficiency in research. ${ }^{25,26,27,28}$ One way of determining the level of established cooperation is by counting the number of coauthorships amongst authors involved in an area of scientific research. The co-authorship relationship occurs when two or more authors or institutions simultaneously contribute to the same scientific article. ${ }^{28,29}$ These interpersonal and interinstitutional collaborations between researchers can be represented by graphs, using social network analysis, which quantify how many members make up a network, what the intensity of the relationship is between its members and who are the most relevant. ${ }^{28,30,31}$ Researchers with the largest number of collaborative publications with other authors are at the 'research front' of that area. ${ }^{32,33}$

The aim of this article was to analyse the scientific activity of researchers in South Africa in viticulture and oenology by using bibliographic analyses of articles in the Science Citation Index (SCI) during the period 1990-2009. The length of the analysed time period allowed us to obtain comprehensive information with which to establish trends of research in the area. Moreover, the joint analyses of productivity, collaboration and scientific impact provides a global and integrated vision of the country's research in this area.

\section{Methods and data sources}

As in other bibliometric studies, ${ }^{19}$ the articles under analyses were obtained from the SCI database, accessed via the Web of Knowledge platform from terminals at Stellenbosch University (Western Cape, South Africa). For the definition of the research field 'wine research', we used a strategy similar to that employed by Glanzel and Veugelers ${ }^{34}$ in a previous article published in the American Journal of Enology and Viticulture. The delineation of the area was based on a search strategy combining two components, (1) specific search strings, and (2) core journals. According to these authors, this set of search terms was the result of a series of previous strategies tested for the data retrieval. The search strategy employed the following terms: barrel fermentation, cava, champagne*, charmant, enolog*, grapevine, grapevines, icewine*, malolactic fermentation, vine*, vineyard, viticultur*, vitis vinifera, wine*, winemaker*. The search was restricted to the field 'topic', which retrieves matching records if the aforementioned terms are included in the titles, keywords or abstracts of articles. In some terms the root was used (cutting the word with an asterisk) to obtain all the documents associated with the derived words (e.g. by using the truncation enolog*, the SCI database finds enology, enological, enologist, etc.). As a result of this search, all articles in the following SCI specific viticulture and oenology journals were obtained: American Journal of Enology and Viticulture, Australian Journal of Grape and Wine Research, Ciencia e Técnica Vitivinícola, Journal International des Sciences de la Vigne et du Vin, South African Journal of Enology and Viticulture and Vitis. Finally, we limited the search to articles that were co-authored by at least one author from a South
African institution, by including the word 'South Africa' in the 'address' field of the search options.

The analysis was limited to 20 years (the period from 1990 to 2009) and to research articles, including original articles, reviews, letters and editorials, but excluding book reviews, summaries of communications at conferences, reprints, news and bibliographic articles. All records obtained were manually reviewed to ensure their relevance.

The final records were exported to a relational database using the proprietary software Bibliometric. ${ }^{35}$ The different variants of the names of the same author or institution were unified because this information was not always standardised in SCI. The information was then analysed to obtain bibliometric indicators and to identify all combinations of pairs of authors and institutions in each article, quantifying the number of coauthorships, that is, the presence of joint signatures of authors or institutions in different articles. This information formed the basis for identifying research groups. The software Pajek, designed for the analysis and visualisation of network ${ }^{36}$ was used for the construction and graphic representation of the research groups.

\section{Results}

\section{General data: Annual productivity and journals}

During the 1990-2009 period 406 articles were published, consisting of 373 original articles (91.9\%), 23 reviews (5.7\%), 6 letters (1.5\%) and 4 editorials (0.9\%). The majority of articles (53.2\%) were published in the last 5 years (Figure 1), with 2007 being the most productive year $(n=52)$. With the exception of Australia, all countries had a similar productivity pattern of about 200 scientific publications in the last 5 years; South Africa and Chile were particularly similar.

A total of 22 journals had four or more published articles on viticulture and oenology (Table 1). The 406 articles were published in 193 journals; the South African Journal of Enology

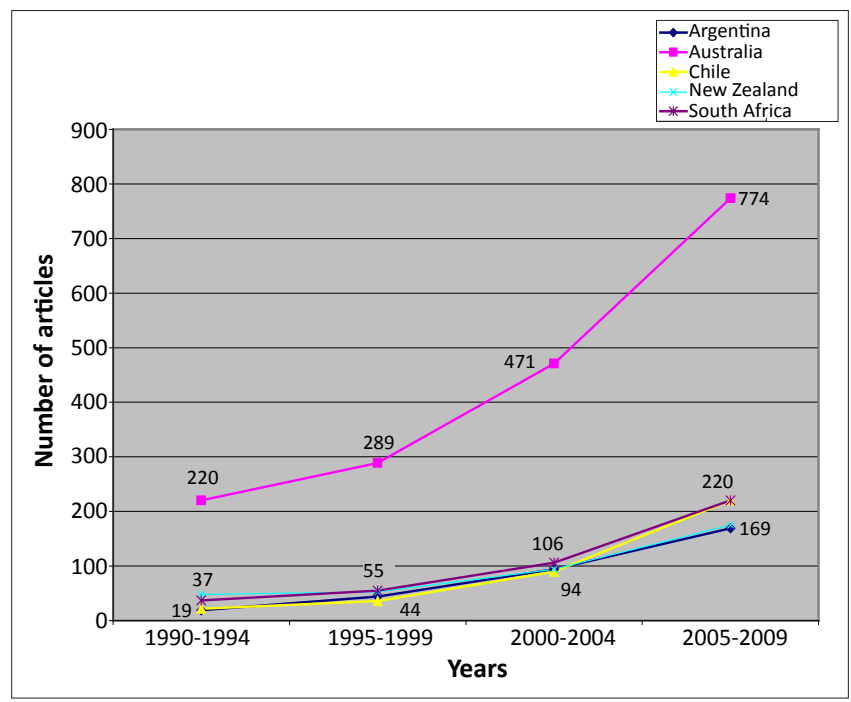

FIGURE 1: The number of articles published between 1990 and 2009 by the most important wine-producing nations in the southern hemisphere. 
and Viticulture published the most articles (34), followed by the American Journal of Enology and Viticulture and the Journal of Agricultural and Food Chemistry (both with 16 articles). The journals with the highest impact factors were Studies in Mycology (6.349), Journal of Chromatography (4.101) and Applied and Environmental Microbiology (3.686).

\section{Author productivity and citations}

The 406 articles were published by 851 different authors, of whom $628(73.8 \%)$ appeared only once (Table 2$)$. The most productive author was Isak S. Pretorius with 40 articles, followed by Pieter W. Crous (19 articles) and Pierre van Rensburg and Florian F. Bauer (18 articles each). As far as the citations are concerned, $83.3 \%$ of the authors were cited at least once and the remaining $16.7 \%$ received no citations. The most cited authors were Isak S. Pretorius (856 citations) and Hennie J.J. van Vuuren (321 citations). Five authors are not included in Table 2 because they published only one article that received 290 citations: M.I. Gil, F.A. Tomas-Barberan, B. Hess-Pierce, D.M. Holcroft and A.A. Kadewr. Following these authors are Florian F. Bauer (282 citations), P.W. Crous (279 citations) and M.G. Lambrechts (273 citations).

\section{Institutional productivity and citations}

A total of 236 institutions were given in the published articles. Stellenbosch University contributed the most publications (219), followed by the Agricultural Research Council (Infruitec-Nietvoorbij, Stellenbosch) with 49 and the Universities of Cape Town and Pretoria with 32 and 31, respectively (Table 3). Because the literature search was limited to articles that were signed by South African institutions, foreign institutions who published an article in conjunction with them, such as the Australian Wine Research Institute, Centraalbureau voor Schimmelcultures (the Netherlands), University of Guelph (Canada), Ghent University (Belgium), Agricultural Research Service (US Department of Agricultural), University of Castilla-La Mancha (Spain) and Universität Zürich (Switzerland) are also listed in Table 3. The most cited institution was Stellenbosch University ( $n=2592)$, followed by the Agricultural Research Council (Infruitec-Nietvoorbij, Stellenbosch) $(n=454)$ and Consejo Superior de Investigaciones Científicas (Spain) $(n=342)$.

\section{Indicators of collaboration and networks}

The collaboration index (the average number of authors per article) was 3.7 for the whole period under investigation, increasing from 2.7 in the first 10 years to 3.9 in the last 10 years (results not shown). Regarding collaboration between institutions, 130 articles (31.1\%) were produced with domestic collaboration, 156 (37.3\%) with international collaboration and 132 with no collaboration (31.6\%). The percentage of articles produced with international collaboration increased over the period analysed, from $16.2 \%$ in the $1990-1994$ period to $44 \%$ in the 2005-2009 time frame, whilst the percentage of articles produced with no collaboration decreased from $45.9 \%$ to $25 \%$ between these two periods. Domestic collaboration remained fairly constant at about 30\% of articles (Figure 2). Foreign institutions collaborating were from 40 countries (Table 4$)$, with Australia $(n=31)$, the USA $(n=27)$ and the Netherlands $(n=20)$ being major partners. Countries with more than 300 citations included those from South Africa $(n=$ $4453)$, followed by the USA $(n=678)$, Spain $(n=388)$, Belgium $(n=351)$, the Netherlands $(n=337)$ and Australia $(n=305)$.

TABLE 1: Number of viticulture and oenology articles published during 1990-2009 by journal, journal impact factor and country of publication.

\begin{tabular}{|c|c|c|c|c|c|c|c|}
\hline \multirow[t]{2}{*}{ Journal title } & \multicolumn{5}{|c|}{ Articles } & \multirow{2}{*}{$\begin{array}{l}2009 \text { Impact } \\
\text { factor }\end{array}$} & \multirow[t]{2}{*}{ Country } \\
\hline & 1990-1994 & 1995-1999 & 2000-2004 & 2005-2009 & Total & & \\
\hline South African Journal of Enology and Viticulture & - & - & - & 34 & 34 & 0.314 & South Africa \\
\hline American Journal of Enology and Viticulture & 10 & 2 & 2 & 2 & 16 & 1.171 & USA \\
\hline Journal of Agricultural and Food Chemistry & - & - & 6 & 10 & 16 & 2.469 & USA \\
\hline Vitis & 1 & 6 & 3 & 1 & 11 & 0.800 & Germany \\
\hline South African Journal of Science & - & - & 5 & 6 & 11 & 0.506 & South Africa \\
\hline Australasian Plant Pathology & - & - & 5 & 6 & 11 & 0.943 & Australia \\
\hline Plant Disease & 1 & 3 & 3 & 1 & 8 & 2.121 & USA \\
\hline Yeast & 1 & 3 & 2 & 1 & 7 & 1.805 & England \\
\hline African Entomology & - & 1 & 1 & 5 & 7 & 0.420 & South Africa \\
\hline Mycologia & - & - & 3 & 4 & 7 & 1.587 & USA \\
\hline International Journal of Food Microbiology & - & - & 4 & 2 & 6 & 3.011 & Netherlands \\
\hline Journal International des Sciences de la Vigne et du Vin & - & - & - & 5 & 5 & 0.771 & France \\
\hline European Journal of Plant Pathology & - & - & 2 & 3 & 5 & 1.931 & Netherlands \\
\hline Applied and Environmental Microbiology & - & - & 3 & 2 & 5 & 3.686 & USA \\
\hline Water SA & 1 & 1 & 3 & - & 5 & 0.911 & South Africa \\
\hline Annals of Microbiology & - & - & 3 & 2 & 5 & 0.358 & Italy \\
\hline Journal of Chromatography A & - & - & 3 & 1 & 4 & 4.101 & Netherlands \\
\hline Studies in Mycology & - & - & - & 4 & 4 & 6.349 & Netherlands \\
\hline Australian Journal of Grape and Wine Research & - & - & 1 & 3 & 4 & 1.872 & Australia \\
\hline FEMS Yeast Research & - & - & 2 & 2 & 4 & 1.785 & Netherlands \\
\hline Applied Microbiology and Biotechnology & 1 & - & 1 & 2 & 4 & 2.896 & USA \\
\hline
\end{tabular}


TABLE 2: Authors with five or more published viticulture and oenology articles and citations during 1990-2009.

\begin{tabular}{|c|c|c|c|c|c|c|c|c|c|c|}
\hline \multirow[t]{2}{*}{ Author } & \multicolumn{5}{|c|}{ Articles } & \multicolumn{5}{|c|}{ Citations } \\
\hline & 1990-1994 & 1995-1999 & 2000-2004 & 2005-2009 & Total & 1990-1994 & 1995-1999 & 2000-2004 & 2005-2009 & Total \\
\hline Pretorius, Isak S & 3 & 3 & 21 & 13 & 40 & 72 & 82 & 609 & 93 & 856 \\
\hline Crous, Pedro W & - & - & 9 & 10 & 19 & - & - & 202 & 77 & 279 \\
\hline Van Rensburg, Pierre & 1 & 1 & 9 & 7 & 18 & 24 & 42 & 124 & 19 & 209 \\
\hline Bauer, Florian F & - & 3 & 3 & 12 & 18 & - & 126 & 94 & 62 & 282 \\
\hline Goszczynski, Dariusz E & - & 4 & 4 & 8 & 16 & - & 73 & 45 & 52 & 170 \\
\hline Fourie, Paul H & - & - & 5 & 10 & 15 & - & - & 96 & 71 & 167 \\
\hline Otero, Ricardo R Cordero & - & - & 7 & 7 & 14 & - & - & 93 & 30 & 123 \\
\hline Lambrechts, Marius G & - & - & 10 & 4 & 14 & - & - & 233 & 40 & 273 \\
\hline Du Toit, Maret & - & 1 & 3 & 10 & 14 & - & 32 & 52 & 12 & 96 \\
\hline Hunter, JJ & 4 & 5 & 1 & 2 & 12 & 76 & 63 & 4 & - & 143 \\
\hline Halleen, Francois & - & - & 6 & 6 & 12 & - & - & 163 & 57 & 220 \\
\hline Van Vuuren, Hennie JJ & 4 & 4 & 2 & 1 & 11 & 151 & 130 & 22 & 18 & 321 \\
\hline Dicks, Leon MT & 2 & 2 & 3 & 4 & 11 & 62 & 44 & 44 & 20 & 170 \\
\hline De Villiers, Andre & - & - & 5 & 4 & 9 & - & - & 79 & 15 & 94 \\
\hline Viljoen-Bloom, M & 1 & 3 & 5 & - & 9 & 31 & 90 & 68 & - & 189 \\
\hline Mostert, Lizel & - & - & 4 & 5 & 9 & - & - & 75 & 45 & 120 \\
\hline Du Toit, Wessel Johannes & - & - & 2 & 6 & 8 & - & - & 27 & 23 & 50 \\
\hline Vivier, Melane A & - & 1 & 4 & 3 & 8 & - & 32 & 101 & 19 & 152 \\
\hline Groenewald, Johannes Z & - & - & 3 & 5 & 8 & - & - & 79 & 51 & 130 \\
\hline Volschenk, Heinrich & - & 2 & 3 & 2 & 7 & - & 86 & 39 & 20 & 145 \\
\hline Holz, G & - & 4 & 3 & - & 7 & - & 56 & 29 & - & 85 \\
\hline Joubert, E & - & - & 1 & 6 & 7 & - & - & 45 & 47 & 92 \\
\hline Archer, $\mathrm{E}$ & - & - & - & 7 & 7 & - & - & - & 10 & 10 \\
\hline Crouch, Andrew M & - & - & 3 & 4 & 7 & - & - & 30 & 25 & 55 \\
\hline Lynen, Frederic & - & - & 3 & 3 & 6 & - & - & 30 & 15 & 45 \\
\hline Botha, Frederik C & - & - & 4 & 2 & 6 & - & - & 15 & 2 & 17 \\
\hline Subden, RE & 1 & 4 & 1 & - & 6 & 31 & 130 & 13 & - & 174 \\
\hline Nieuwoudt, Helene $\mathrm{H}$ & - & - & 1 & 5 & 6 & - & - & 27 & 15 & 42 \\
\hline Blackhurst, DM & - & - & - & 5 & 5 & - & - & - & 4 & 4 \\
\hline Britz, TJ & - & 1 & 1 & 3 & 5 & - & 3 & 22 & 8 & 33 \\
\hline Burger, AL & - & - & 4 & 1 & 5 & - & - & 15 & 0 & 15 \\
\hline Bauer, Rolene & - & - & 2 & 3 & 5 & - & - & 26 & 23 & 49 \\
\hline Burgess, Joanna E & - & - & - & 5 & 5 & - & - & - & 10 & 10 \\
\hline Van Zyl, Willem H & 1 & 1 & - & 3 & 5 & 24 & 42 & - & 13 & 79 \\
\hline Ekama, GA & 1 & - & 4 & - & 5 & 4 & - & 55 & - & 59 \\
\hline Witthuhn, R Corli & - & - & 1 & 4 & 5 & - & - & 22 & 9 & 31 \\
\hline McLeod, Adele & - & - & - & 5 & 5 & - & - & - & 31 & 31 \\
\hline Wentzel, MC & 1 & - & 4 & & 5 & 4 & - & 55 & - & 59 \\
\hline De Beer, D & - & - & 1 & 4 & 5 & - & - & 45 & 29 & 74 \\
\hline Ruffner, HP & 1 & 3 & 1 & - & 5 & 17 & 60 & 4 & - & 81 \\
\hline
\end{tabular}

A threshold of three articles co-authored between authors has been used for a representation of networks of collaboration. Using this threshold, 18 different groups were drawn with different components or numbers of authors in each group (Figure 3). The largest group had 21 components and the central author was Pretorius, who established co-authorship relations with eight other authors, amongst them Van Rensburg (with whom he published 14 articles), and Otero and Lambrechts, with whom he published 10 articles each. Otero also occupied a prominent, central position and had collaborations with seven other authors, including Bauer, Subden and Van Vuuren, who each had five other collaborators. Two groups of seven components each were also found; these central authors were Goszacynski and Crous, respectively. Other smaller groups were also found: one group of six authors, two groups of five authors, five groups of three authors and seven groups of two authors.

Stellenbosch University was situated in a central position in the network where a threshold of two co-authored articles was used (Figure 4), with its most regular collaborations having been with the Agricultural Research Council (39 articles), the Australian Wine Research Institute (19 articles) and Distell Group Limited South Africa (16 articles). Other centres that also occupied a central position, although less strongly, were the University of Pretoria, the Australian 
TABLE 3: Institutions that published viticulture and oenology articles and received citations during 1990-2009.

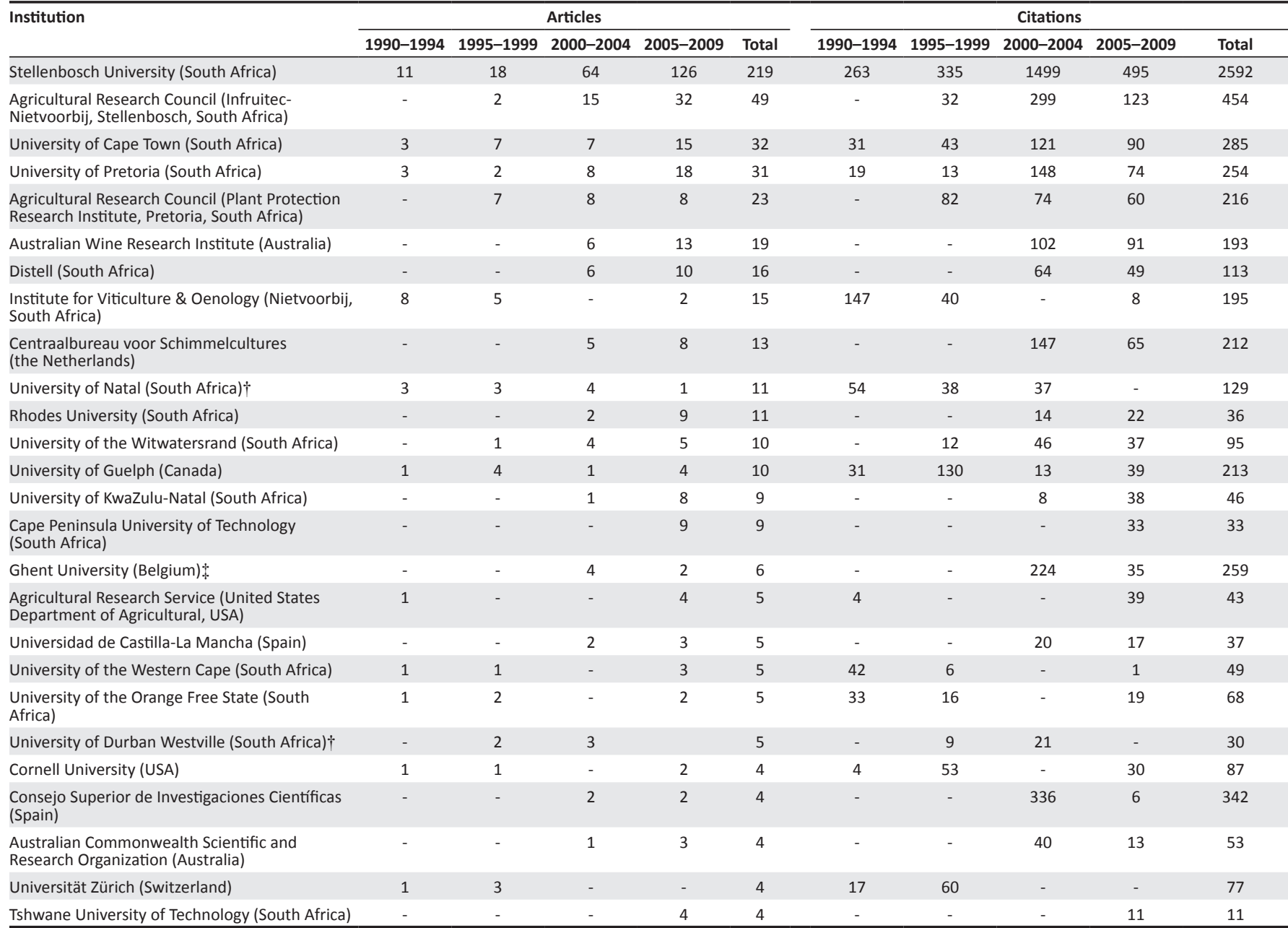

$\uparrow$ On 1 January 2004, the University of Natal merged with the University of Durban-Westville to form the University of KwaZulu-Natal.

$\$$, In 1991, Ghent University was granted major autonomy and changed its name from State University of Ghent to Ghent University.

Wine Research Institute, Distell Group Limited South Africa, Cape Peninsula University of Technology (Cape Town, South Africa), Dipartimento Colture Arboree (Palermo, Italy) and University of Guelph (Ontario, Canada). South Africa collaborated with Australia on 31 articles, with the USA on 27 articles and with the Netherlands on 20 articles (Figure 5).

\section{Most cited articles}

The most cited article was that of Gil and colleagues published in 2000 in the Journal of Agricultural and Food Chemistry. This article was cited 290 times (Table 5). The only other article to have been cited more than 200 times was that of Pretorius published in the same year in the journal Yeast, with 218 citations.

\section{Discussion}

Viticulture and oenology is a growing field of scientific research. Bibliometric methods allow the characterisation of the size, growth and distribution of scientific publications, identifying the most productive, influential and prestigious authors and institutions. A co-authorship network analysis offers a perspective on research groups and the position of the most outstanding researchers.

There were four major limitations in this study. Firstly, bibliographic data in the SCI database are not standardised, which leads to the same author or institutional affiliation

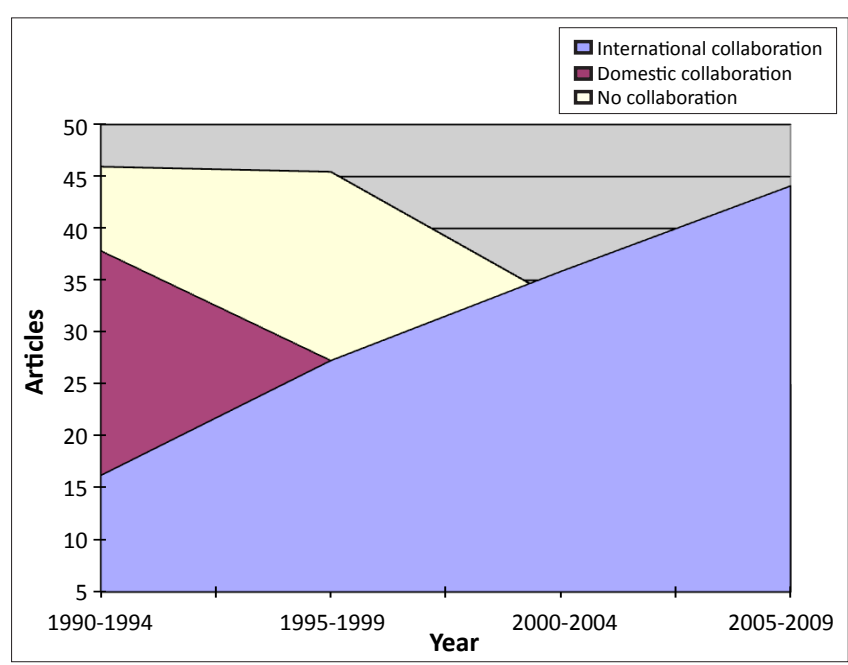

FIGURE 2: Changes in domestic and international collaboration of South African viticulture and oenology institutions between 1990 and 2009. 
TABLE 4: The number of viticulture and oenology articles and citations during 1990-2009, by country.

\begin{tabular}{|c|c|c|c|c|c|c|c|c|c|c|}
\hline \multirow[t]{2}{*}{ Country } & \multicolumn{5}{|c|}{ Articles } & \multicolumn{5}{|c|}{ Citations } \\
\hline & 1990-1994 & 1995-1999 & $2000-2004$ & 2005-2009 & Total & 1990-1994 & 1995-1999 & $2000-2004$ & $2005-2009$ & Total \\
\hline South Africa & 37 & 55 & 106 & 220 & 418 & 561 & 659 & 2313 & 920 & 4453 \\
\hline Australia & 1 & - & 8 & 22 & 31 & 4 & - & 149 & 152 & 305 \\
\hline USA & 2 & 4 & 5 & 16 & 27 & 38 & 155 & 336 & 149 & 678 \\
\hline Netherlands & - & - & 7 & 13 & 20 & - & - & 228 & 109 & 337 \\
\hline Canada & 1 & 4 & 3 & 7 & 15 & 31 & 130 & 68 & 64 & 293 \\
\hline France & 1 & 2 & 1 & 10 & 14 & 4 & 86 & 46 & 61 & 197 \\
\hline Belgium & - & - & 7 & 6 & 13 & - & - & 308 & 43 & 351 \\
\hline Spain & - & - & 4 & 9 & 13 & - & - & 356 & 32 & 388 \\
\hline Switzerland & 3 & 3 & 1 & 3 & 10 & 23 & 60 & 4 & 17 & 104 \\
\hline UK & - & 2 & 1 & 5 & 8 & - & 11 & 7 & 10 & 28 \\
\hline Germany & 1 & 1 & & 5 & 7 & 17 & 3 & - & 26 & 46 \\
\hline Italy & 1 & 2 & 1 & 3 & 7 & 4 & 41 & 49 & 1 & 95 \\
\hline Israel & 1 & - & 1 & 3 & 5 & 4 & - & 15 & 11 & 30 \\
\hline Slovakia & - & - & 1 & 2 & 3 & - & - & 31 & 15 & 46 \\
\hline Slovenia & - & - & - & 2 & 2 & - & - & - & 10 & 10 \\
\hline Peoples Republic of China & - & - & - & 2 & 2 & - & - & - & 5 & 5 \\
\hline Norway & - & - & - & 2 & 2 & - & - & - & 9 & 9 \\
\hline Nigeria & - & - & - & 2 & 2 & - & - & - & 1 & 1 \\
\hline Zimbabwe & - & - & 2 & - & 2 & - & - & 16 & - & 16 \\
\hline Croatia & - & - & 2 & - & 2 & - & - & 43 & - & 43 \\
\hline Sweden & - & - & 1 & 1 & 2 & - & - & 31 & - & 31 \\
\hline Austria & - & 1 & & 1 & 2 & - & 35 & - & - & 35 \\
\hline Portugal & - & - & 1 & 1 & 2 & - & - & 20 & 10 & 30 \\
\hline Czech Republic & - & - & - & 1 & 1 & - & - & - & 1 & 1 \\
\hline Byelarus & - & - & - & 1 & 1 & - & - & - & 1 & 1 \\
\hline Brazil & - & - & - & 1 & 1 & - & - & - & 5 & 5 \\
\hline Denmark & - & - & - & 1 & 1 & - & - & - & 4 & 4 \\
\hline Iran & - & - & - & 1 & 1 & - & - & - & 4 & 4 \\
\hline Argentina & - & - & - & 1 & 1 & - & - & - & 1 & 1 \\
\hline New Zealand & - & - & - & 1 & 1 & - & - & - & - & 0 \\
\hline Romania & - & - & - & 1 & 1 & - & - & - & 1 & 1 \\
\hline South Korea & - & - & - & 1 & 1 & - & - & - & 4 & 4 \\
\hline Sri Lanka & - & - & - & 1 & 1 & - & - & - & 11 & 11 \\
\hline Thailand & - & 1 & - & - & 1 & - & 4 & - & - & 4 \\
\hline Uruguay & - & - & - & 1 & 1 & - & - & - & - & 0 \\
\hline Venezuela & - & - & - & 1 & 1 & - & - & - & 17 & 17 \\
\hline Namibia & - & - & - & 1 & 1 & - & - & - & 4 & 4 \\
\hline
\end{tabular}

TABLE 5: Most cited viticulture and oenology articles published between 1990 and 2009.

\begin{tabular}{|c|c|c|c|c|}
\hline Authors & Year of publication & Article title & Source & $\begin{array}{l}\text { Number of } \\
\text { citations }\end{array}$ \\
\hline $\begin{array}{l}\text { Gil MI, Tomas-Barberan FA, } \\
\text { Hess-Pierce B, Holcroft DM, Kadewr AA }\end{array}$ & 2000 & $\begin{array}{l}\text { Antioxidant activity of pomegranate juice and its } \\
\text { relationship with phenolic composition and processing }\end{array}$ & $\begin{array}{l}\text { Journal of Agricultural and } \\
\text { Food Chemistry } 48: 4581-4589\end{array}$ & 290 \\
\hline Pretorius IS & 2000 & $\begin{array}{l}\text { Tailoring wine yeast for the new millennium: Novel } \\
\text { approaches to the ancient art of winemaking }\end{array}$ & Yeast 16:675-729 & 218 \\
\hline $\begin{array}{l}\text { Sandra P, Tienpont B, Vercammen J, } \\
\text { Tredoux A, Sandra T }\end{array}$ & 2001 & $\begin{array}{l}\text { Stir bar sorptive extraction applied to the } \\
\text { determination of dicarboximide fungicides in wine }\end{array}$ & $\begin{array}{l}\text { Journal of Chromatography } \\
\text { A 928:117-126 }\end{array}$ & 98 \\
\hline Sandra P, Tienpont B, David F & 2003 & $\begin{array}{l}\text { Multi-residue screening of pesticides in vegetables, } \\
\text { fruits and baby food by stir bar sorptive extraction- } \\
\text { thermal desorption-capillary gas chromatography- } \\
\text { mass spectrometry }\end{array}$ & $\begin{array}{l}\text { Journal of Chromatography } \\
\text { A 1000:299-309 }\end{array}$ & 77 \\
\hline $\begin{array}{l}\text { Van der Gaag MS, Ubbink JB, } \\
\text { Sillanaukee P, Nikkari S, Hendriks HFJ }\end{array}$ & 2000 & $\begin{array}{l}\text { Effect of consumption of red wine, spirits, and } \\
\text { beer on serum homocysteine }\end{array}$ & Lancet 35:1522-1522 & 74 \\
\hline Lilly M, Lambrechts MG, Pretorius IS & 2000 & $\begin{array}{l}\text { Effect of increased yeast alcohol acetyltransferase } \\
\text { activity on flavor profiles of wine and distillates }\end{array}$ & $\begin{array}{l}\text { Applied and Environmental } \\
\text { Microbiology } 66: 744-753\end{array}$ & 74 \\
\hline $\begin{array}{l}\text { Volschenk H, Viljoen-Bloom M, } \\
\text { Grobler J, Petzold B, Bauer FF }\end{array}$ & 1997 & $\begin{array}{l}\text { Engineering pathways for malate } \\
\text { degradation in Saccharomyces cerevisiae }\end{array}$ & $\begin{array}{l}\text { Nature Biotechnology } \\
15: 253-257\end{array}$ & 62 \\
\hline Van Vuuren HJJ, Dicks LMT & 1993 & Leuconostoc oenos - A review & $\begin{array}{l}\text { American Journal of Enology } \\
\text { and Viticulture } 44: 99-112\end{array}$ & 55 \\
\hline $\begin{array}{l}\text { Zhu HY, Ling KS, Goszczynski DE, } \\
\text { McFerson JR, Gonsalves D }\end{array}$ & 1998 & $\begin{array}{l}\text { Nucleotide sequence and genome organization } \\
\text { of grapevine leafroll-associated virus- } 2 \text { are similar } \\
\text { to beet yellows virus, the closterovirus type member }\end{array}$ & $\begin{array}{l}\text { Journal of General Virology } \\
79: 1289-1298\end{array}$ & 53 \\
\hline
\end{tabular}




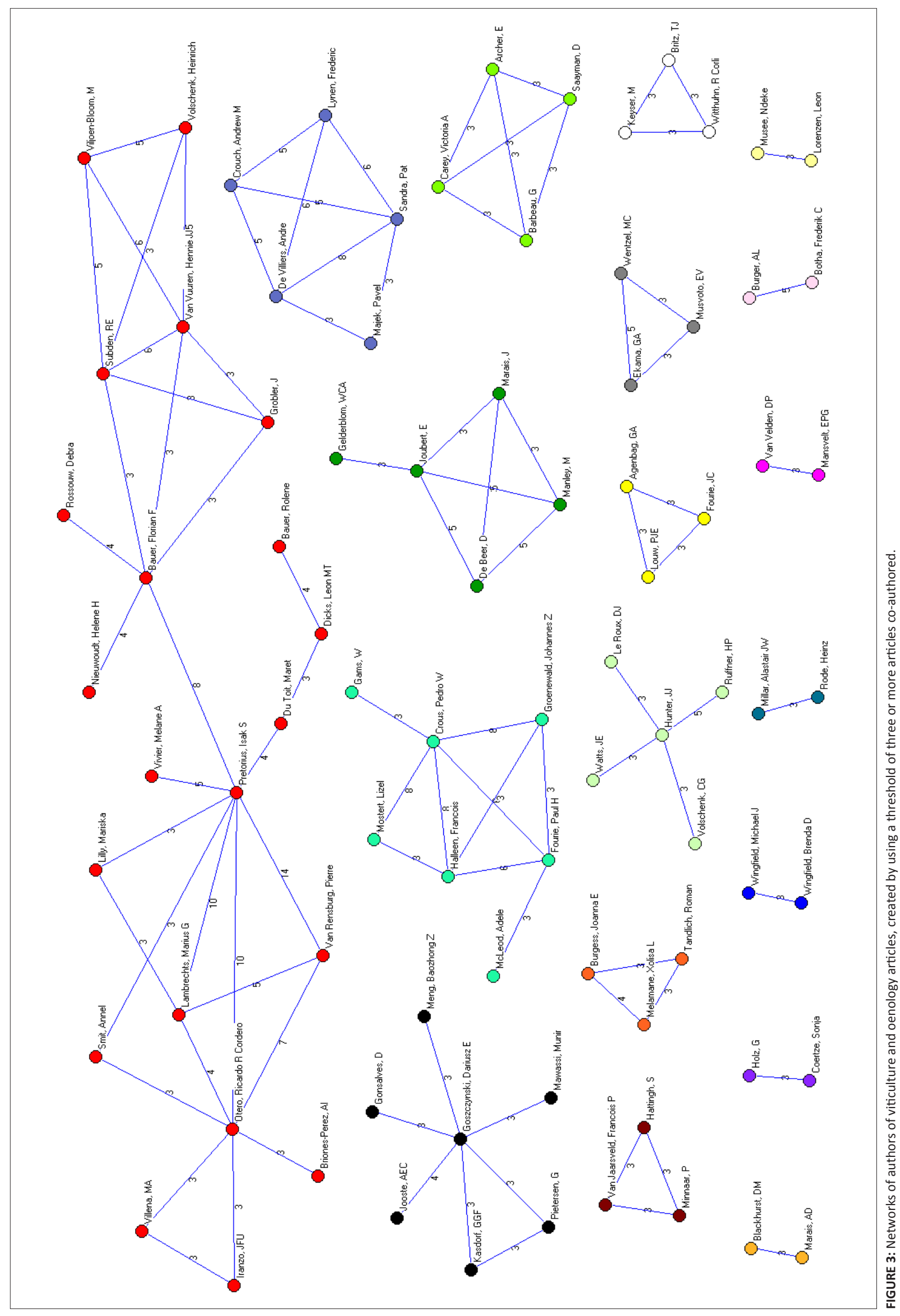




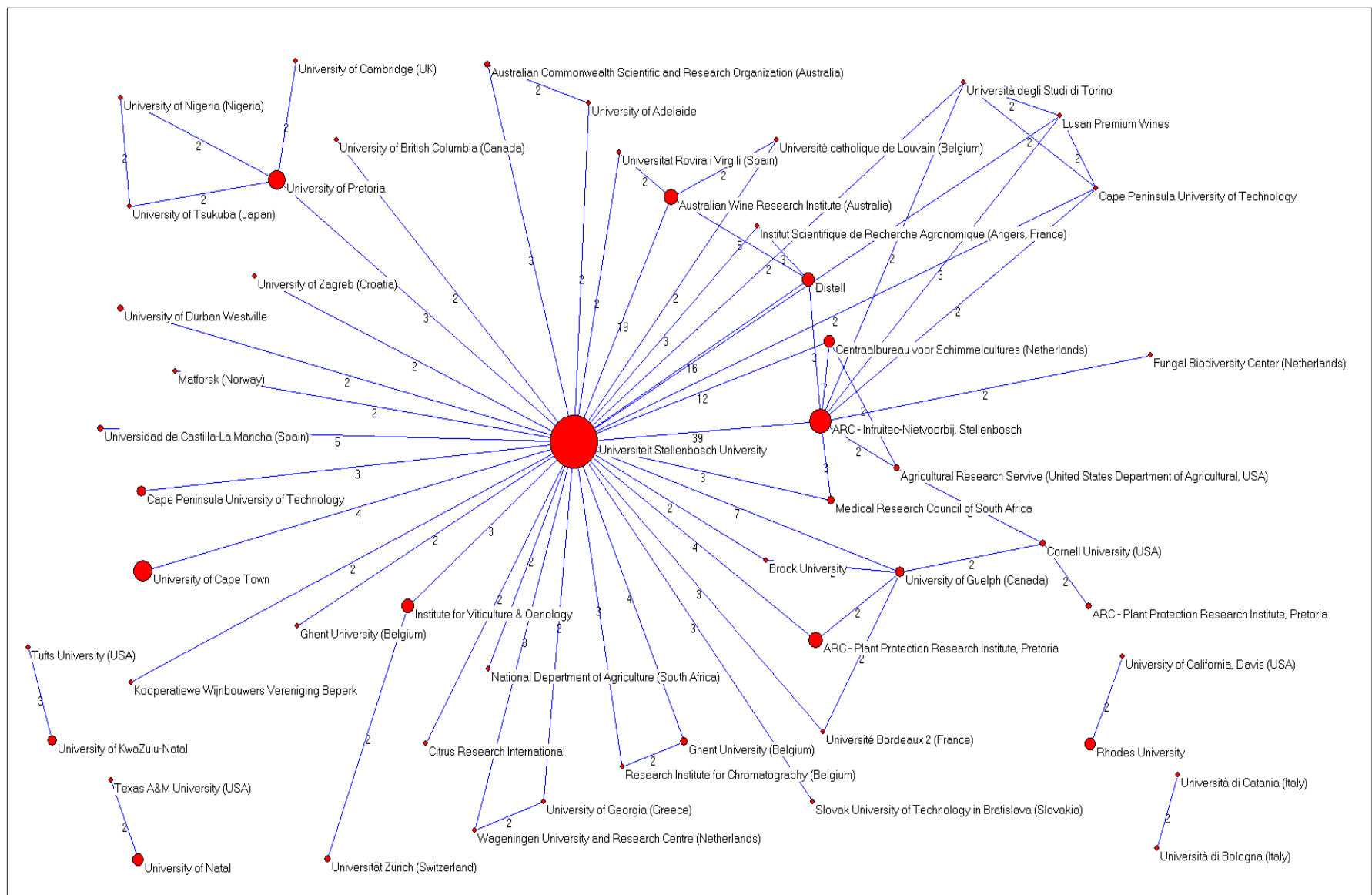

FIGURE 4: Networks of institutions publishing viticulture and oenology research, created by using a threshold of two or more collaborative articles.

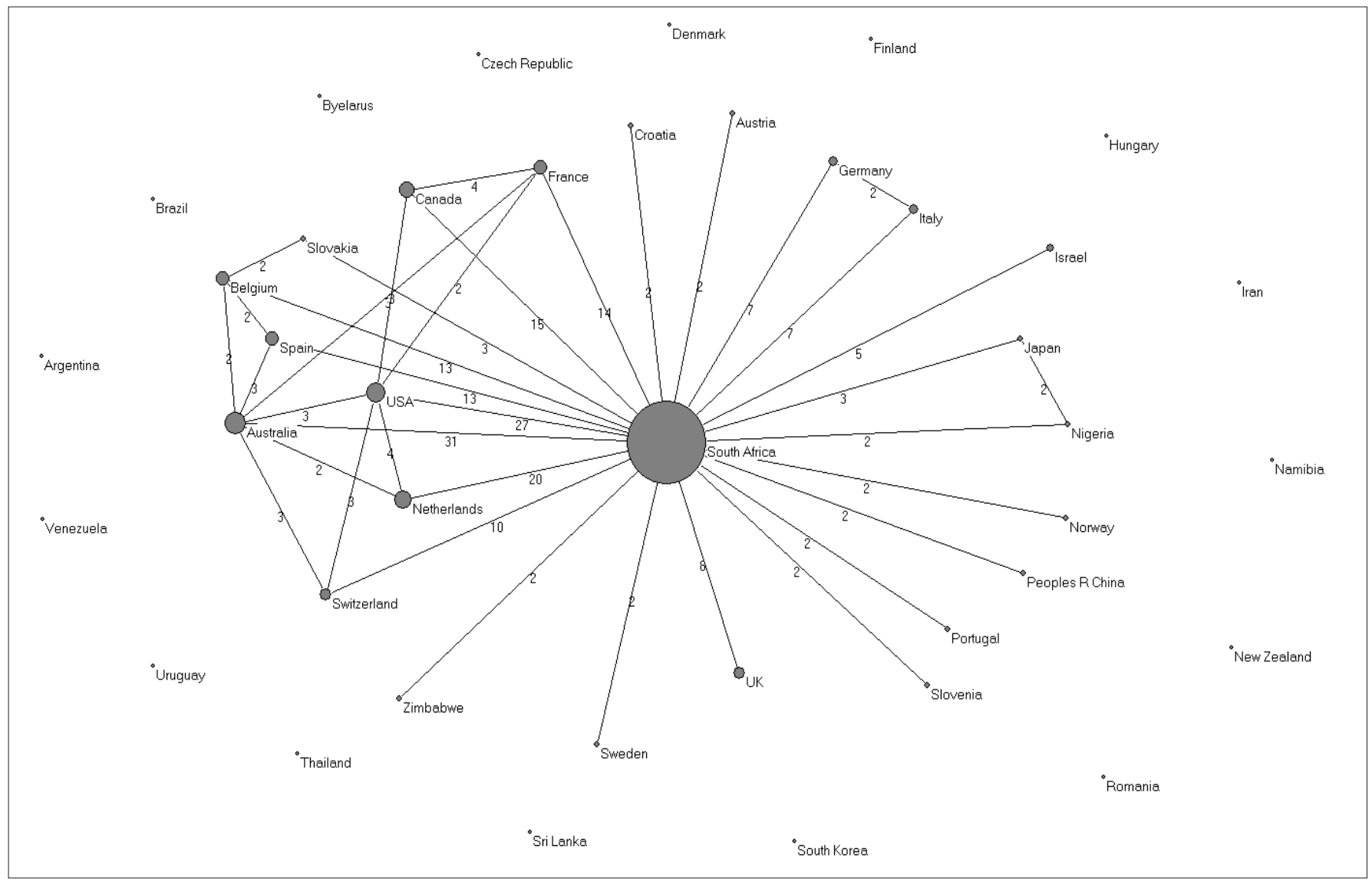

FIGURE 5: Networks of countries of origin of viticulture and oenology articles, created by using a threshold of two or more collaborative articles. 
appearing under different names. To unify these variants, a careful manual standardisation was performed, in which directories of universities and research centres, as well as their respective websites, were checked.

Secondly, the SCI database does not include all the published scientific literature on viticulture and oenology, and other bibliographic databases and additional data gathering from local South African science journals could have been used as an alternative or supplement, as pointed out by Tijssen et al. ${ }^{37}$ However, the use of SCI as a source of information in this article had the following advantages:

1. It provided all the authors who signed the articles and all their institutional affiliations, allowing us to obtain indicators of collaboration between authors and institutions.

2. It provided the number of citations the articles had received and, therefore, determined the number of citations of their authors and institutions. Moreover, the database provided the JCR impact factor of the journals - information which is not present in other databases.

3. SCI is a source widely used in studies examining the scientific activity in the various fields of science and technology because it includes the highest impact journals and helps to achieve the objective of focusing the analyses on the most relevant authors and institutions, identifying and characterising the production and scientific impact of the research front in the analysed area.

In order to identify the gap in data collection when using SCI as a sole source of information, we analysed three annual research reports of the Department of Viticulture and Enology at Stellenbosch University. Of the 42 articles published from 2007 to 2009, 15 (36\%) were published in international peer-reviewed journals and $27(64 \%)$ in local journals, most of which were published in Afrikaans in the journals Wynboer and SA Fruit Journal.

Thirdly, the social network analysis based on co-authorship of scientific articles has only recently been studied. ${ }^{38}$ For this reason, we have not found similar works in the scientific literature that have analysed the research and social networks of viticulture and oenology from the point of view of publications.

Lastly, the identification of the articles used in this study, the authors and partnerships, did not allow us to investigate in more detail the contribution of each to the advancement and dissemination of knowledge, beyond their citation in later publications.

Despite the aforementioned limitations, this work identified the most productive authors and institutions in the field of South African viticulture and oenology during the period investigated. The composition of research groups that can be considered to be at the forefront of research in this area were also identified. ${ }^{28}$

Two distinct periods in the annual evolution of the number of published articles were observed: one from 1990 to early
2004, with a moderate production of between 10 and 20 articles per year, and a second from 2005 to 2009, in which there was a notable growth to an average of 44 articles per year. A reason for this increase could be the inclusion of the South African Journal of Enology and Viticulture in SCI in 2005. (This journal has been published in English since 1980 by the South African Society for Enology and Viticulture.) Other reasons could also be the increasing number of South African journals included in $\mathrm{SCI}^{19}$ - from 19 in 2001 to 29 in 2009 - as well as an increase in the number of articles published in other journals such as American Journal of Enology and Viticulture, South African Journal of Science and African Entomology. However, there remains a poor coverage of South African journals in international bibliographic databases (in particular SCI). Consequently, higher-quality articles originated in South Africa are usually published in American or European journals. These journals have a privileged position in the mainstream of science and they are able to attract the leading scientists' articles. The small size of the South African scientific community and their position at the periphery of science are other factors that may contribute to the low impact factors of South African journals. The growth of research in viticulture and oenology in South Africa has also been observed in other scientific areas. Molatudi et al. ${ }^{16}$ found that $65 \%$ of South African literature in bioinformatics since 1990 was published in the period 2001-2006. In Medicine, the number of articles doubled between 1975 and 2005,,$^{15}$ and in Engineering, the proliferation in the number of articles was almost seven-fold for the same period. ${ }^{17}$ For HIV and AIDS research, the number of publications increased five-fold between 1996 and 2006. ${ }^{18}$ Moreover, the importance of South African scientific output in the area of viticulture and oenology has been highlighted by Glänzel and Veugelers ${ }^{34}$, who ranked South Africa in 15th place in terms of productivity.

The distribution of journal articles can give an idea of the areas covered in the current multidisciplinary viticulture and oenology fields, as many researchers publish in journals specific to other areas such as Food Science and Technology (e.g. Journal of Agricultural and Food Chemistry and International Journal of Food Microbiology), general purpose (South African Journal of Science), Plant Sciences (Australasian Plant Pathology, Plant Disease and European Journal of Plant Pathology), Microbiology and Biotechnology (Yeast, International Journal of Food Microbiology and Journal of Applied Microbiology). This diversity of subject areas should alert researchers seeking information on viticulture and oenology to expand their search to journals in related areas and even general purpose journals. ${ }^{39}$

The most prolific author, I.S. Pretorius, is currently a researcher at the Australian Wine Research Institute (Adelaide, Australia). Researchers at this institution collaborate extensively with many South African researchers, including P. van Rensburg and F.F. Bauer from the Institute of Wine Biotechnology at Stellenbosch University. The second most prolific author, P.W. Crous, is a researcher at Centraalbureau 
for Schimmelcultures (Utrecht, the Netherlands) and also works closely with counterparts in the Department of Plant Pathology at Stellenbosch University. The presence of foreign authors in South African research can be regarded as an objective indicator of the level of international cooperation that keeps the country in the forefront of this field. It is noteworthy that both Pretorius and Crous are South Africans who, before emigrating, held positions at Stellenbosch University.

Stellenbosch University is leading research in viticulture and oenology through the Department of Viticulture and Oenology (http://academic.sun.ac.za/viti_oenol/). Tuition has been offered at Stellenbosch University since the 1880s and the university has a long history of engagement with vine and wine sciences as well as a close association with the South African grape and wine industries. The Institute for Wine Biotechnology was established in 1995 by a team of academics and researchers and was integrated into the Department of Viticulture and Oenology of Stellenbosch University in 2003. The involvement of many foreign institutions (as can be seen in Table 3), especially from Australia, Holland, France and Spain, is therefore not surprising, because the Department maintains contact and active research collaborations with many national and international universities and research organisations. These collaborations involve the establishment of agreements for the exchange of students and foreign researchers, as well as many collaborative research projects. An example of this dynamic in the field of viticulture and oenology is the agreement between the European Union and South Africa through the Erasmus Mundus Vintage International Masters of Science programme (http://www. vintagemaster.com). Erasmus Mundus is a cooperation and mobility programme in the field of higher education that aims to enhance the quality of European higher education and to promote dialogue and understanding between people and cultures through cooperation with developing countries. These agreements enable students, teachers and researchers from countries within the European Union and South Africa to participate in scientific programmes and, thereby, increase their mobility. The promotion of work periods in foreign research centres is considered crucial to promote the internationalisation of science in any country. ${ }^{40}$ As evidenced in this study, there has been a steady increase in international collaboration in the viticulture and oenology area, which also is consistent with the data provided by Sooryamoorthy ${ }^{41}$ for all areas of research in South Africa.

Social network analysis identified the main groups of researchers who had scientific collaborations and whom could be considered at the forefront of their areas, ${ }^{42}$ beyond the formal structures that make up the research institutes and departments of universities and other research institutions. Knowledge of these structures has several advantages for researchers. In the first instance, it provides them with reliable information about existing groups that maintain a high-level research activity - information that provides the possibility of expanding their circle of contacts and participation in discussion forums, and increases the exchange of ideas on relevant topics, as well as allows linking and integration into any of the identified networks. ${ }^{30,31,43}$ Additionally, such information enables researchers to know which institutions work together and which occupy more central roles within the network, which is valuable information when deciding on which institutions could be appropriate to establish collaborative arrangements with, or to conduct metacentre studies. According to Barbasi and Albert ${ }^{44}$, the nodes of a network of a collaboration that already have many connections will be preferentially chosen by new research groups to initiate a scientific collaboration, and a group rich in connections (or collaborations) will increase their influence more rapidly than those with fewer. ${ }^{43}$ Moreover, the identification of groups with similar scientific interests and research lines allows increasing effectiveness in research, as it prevents duplication of experiments. ${ }^{41,44,45,46,47}$ The existence of a group consisting of a small number of researchers with little or no integration with other groups of the same scientific field can be explained by that group possibly being at the beginning of its research activity period. ${ }^{48,49}$ However, the researchers with the largest number of publications are not always at the research front, especially in the case of an extended time window, in this case 20 years (1990-2009), because many of the prolific authors are likely to become heads of departments or lab directors. In this case, we found that 7 of the 14 authors with more than 10 articles were last author on more than $50 \%$ of their articles.

\section{Conclusions}

In conclusion, this study provides indicators to assess the state of South African research in viticulture and oenology and its evolution over the past 20 years, using articles published in international impact scientific journals. In short, we have identified a significant growth in South African research in recent years, with a high degree of internationalisation and a constant level of domestic collaboration. The research is organised mainly around research centres in the country, primarily Stellenbosch University, with the main vehicle for dissemination of this scientific activity being the South African Journal of Enology and Viticulture. The patterns and trends of South African research in this field are similar to other countries from the southern hemisphere, notably Chile, ${ }^{50}$ who has a wine industry that is in many ways in a similar socio-economic position to that of the South African industry.

Future work in this area could identify newly emerging groups and observe the temporal evolution of the groups already recognised, as well as the existence of authors or institutions that remain on the periphery or are isolated from others. ${ }^{31}$

\section{Acknowledgements}

We wish to thank the Department of Viticulture and Oenology of Stellenbosch University for the facilities provided for the development of this work, which is part of the collaborative 
activities of the European Union Erasmus Mundus Programme Action 3 for the exchange of professors and researchers among the members of the Vintage Master Consortium.

\section{Competing interests}

We declare that we have no financial or personal relationships which may have inappropriately influenced us in writing this article.

\section{Authors' contributions}

R.A.-B. was the project leader and wrote the manuscript. J.L.A.-T. searched and reviewed the literature. J.L.A. was responsible for the information concerning viticulture and oenology. G.G.A. was responsible for the statistical treatment. A.F.S. was responsible for the bibliometric analysis. W.d.T. made conceptual contributions and reviewed the manuscript.

\section{References}

1. Aleixandre JL, Crespo F. [National and international wine geography] Valencia: Editorial Intertécnica; 2005. Spanish. 2. Melamane XL, Strong PJ, Burgess JE. Treartment of wine distillery
wastewater: A review with emphasis on anaerobic membrane reactors. S Afr J Enol Vit. 2007;28:25-36.

3. Keyser M, Britz TJ, Witthuhn RC. Fingerprinting and identification of bacteria present in UASB granules used to treat winery, brewery, distillery or peach-lye canning wastewater. S Afr J Enol Vit. 2007;28:69-79.

4. Sigge GO, Green J, Du Plessis KR, Britz TJ. Investigating the effect of ozone on the biodegradability of distillery wastewater. S Afr J Enol Vit. 2007;28:155-162.

5. Zingelwa NS, Wooldridge J. Uptake and accumulation of mineral elements from winery and distillery effluents by Typha latifolia and Phragmites australis. S Afr J Enol Vit. 2009;30:43-48.

6. Vaudour E, Shaw AB. A worldwide perspective on viticultural zoning. S Afr J Enol Vit. 2005;26:106-115.

7. Retief E, Damm U, Van Niekerk JM, McLeod A, Fourie R. A protocol for molecular detection of Phaeomoniella chlamydospora in grapevine wood. S Afr J Sci. 2005;101:139-142.

8. Koopman TA, Linde CC, Fourie PH, McLeod A. Epidemiological importance of Plasmopara viticola oosporic infections in South African vineyards. S Afr J Sci. 2007;103(1/2):9.

9. Pietersen G. Tackling the grapevine leafroll disease problem in South Africa. S Afr J Sci. 2007;103(1/2):2.

10. Van Niekerk JM, Halleen F, Fourie PH. Spore dispersal patterns of grapevine trunk disease pathogens. S Afr J Sci. 2007;103(1/2):8.

11. Minnaar PP, Booyse M. Differentiation between wines according to geographical regions in the Western Cape (South Africa) using multivariate analysis based on selected chemical parameters in young red wines. S Afr J Enol Vit. 2004;25:89-93.

12. Minnaar PP, Rohwer ER, Booyse M. Investigating the use of element analysis for differentiation between the geographic origins of Western Cape wines. S Afr J Enol Vit. 2005;26:95-105

13. De Beer D, Joubert E, Marais J, Du Toit W, Fourie B, Manley M Characterisation of Pinotage wine during maturation on different oak products. S Afr J Enol Vit. 2008;29:39-49.

14. Van Jaarsveld FP, Hatting S, Minnaar P. Rapid induction of ageing character in brandy products. Part I. Effects of extraction media and preparation conditions. S Afr J Enol Vit. 2009;30:1-15.

15. Sooryamoorthy R. Medical research in South Africa: A scientometric analysis of trends, patterns, productivity and partnership. Scientometrics. 2010;84:863-885. http:/ /dx.doi.org/10.1007/s11192-010-0169-9

16. Molatudi M, Moltja N, Pouris A. A bibliometric study of bioinformatics research in South Africa. Scientometrics. 2009;81:47-59. http://dx.doi. org $/ 10.1007 /$ s11192-007-2048-6

17. Sooryamoorthy R. Scientific publications of engineers in South Africa 1975-2005. Scientometrics. 2010;86(1):211-226. http://dx.doi.org/10.1007/ s11192-010-0288-3

18. Pouris A, Pouris A. Scientometrics of a pandemic: HIV/AIDS research in South Africa and the World. Scientometrics. 2010;86(2):541-552. http:// dx.doi.org/10.1007/s11192-010-0277-6

19. Kahn M. A bibliometric analysis of South Africa's scientific outputs - some trends and implications. S Afr J Sci. 2011;107(1/2), Art. \#406, 6 pages. http://dx.doi.org/10.4102/sajs.v107i1/2.406.
20. Vinkler P. Evaluation of some methods for the relative assessment of scientific publications. Scientometrics. 1986;10:157-177. http://dx.doi. org /10.1007/BF02026039

21. White HD, Mccain K. Bibliometrics. Ann Rev Inf Sci Tech. 1989;24:119-186. 22. Van Raan AFJ. Scientometrics: State-of-the-art. Scientometrics. 1997;38:205218. http:/ /dx.doi.org/10.1007/BF02461131

23. Garfield E. The history and meaning of the journal impact factor. J Am Med Assoc. 2006;295:90-93. http://dx.doi.org/10.1001/jama.295.1.90, PMid:16391221

24. Aleixandre-Benavent R, Valderrama Zurian JC, Gonzalez Alcaide G. [The impact factor of scientific journals: Limitations and alternative indicators] Prof Inf. 2007;16:4-11. Spanish.

25. Kretschmer H. Coauthorship networks of invisible college and institutionalized communities. Scientometrics. 1994;30:363-369. http://dx.doi.org/10.1007/ BF02017234

26. Frame JD, Carpenter MP. International research collaboration. Soc Stud Sci. 1979;9:481-497. http:/ /dx.doi.org/10.1177/030631277900900405

27. Katz JS, Martin BR. What is research collaboration? Res Policy. 1997;26:118. http:/ /dx.doi.org/10.1016/S0048-7333(96)00917-1

28. Newman MEJ. Coauthorship networks and patterns of scientific collaboration. Proc Natl Acad Sci USA. 2004;101:5200-5205. http://dx.doi.org/10.1073/ pnas.0307545100, PMid:14745042, PMCid:387296

29. Melin G, Persson O. Studying research collaboration using coauthorships Scientometrics. 1996;36:363-377. http:/ /dx.doi.org/10.1007/BF02129600

30. Gonzalez-Alcaide G, Valderrama-Zurian JC, Aleixandre-Benaven R. Research fronts and collaboration patterns in Reproductive Biology. Coauthorship networks and institutional collaboration. Fertil Steril. 2008;90:941-956. http://dx.doi.org/10.1016/j.fertnstert.2007.07.1378, PMid:18177648

31. Scott JP. Social network analysis: A handbook. London: Sage; 2001.

32. Newman MEJ. The structure of scientific collaboration networks. Proc Nat Acad Sci USA. 2001;98:404-409. http://dx.doi.org/10.1073/pnas.021544898, PMid:11149952

33. Gonzalez-Alcaide G, Alonso Arroyo A, Gonzalez De Dios J, Perez Sempere A, Valderrama Zurian JC, Aleixandre-Benavent R. [Co-authorship networks and institutional collaboration in Revista de Neurología]. Rev Neurol. 2008;46:642-651. Spanish. PMid:18509820

34. Glanzel W, Veugelers R. Science for wine: A bibliometric assessment for wine and grape research for wine-producing and consuming countries. Am J Enol Viticult. 2006;57:23-32.

35. Bibliometrics program. Version 1. Valencia: Spanish Research CouncilCSIC; 2010.

36. Batagelj V, Mrvar A. Pajek program for large network analysis. Slovenia: University of Ljubljana; 2001.

37. Tijssen RJW, Mouton J, Leeuwen TN, Boshoff N. How relevant are local scholarly journals in global science? A case study of South Africa. Res Eval. 2006;15:163-174. http://dx.doi.org/10.3152/147154406781775904

38. Cunningham SJ, Dillon SM. Authorship patterns in information systems Scientometrics. 1997;39:19-27. http://dx.doi.org/10.1007/BF02457428

39. Klein JT. Interdisciplinary needs: The current context. Libr Trends. 1996;45:134-154.

40. Ponds R. The limits to internationalization of scientific research collaboration. J Technol Transf. 2009;34:76-94. http://dx.doi.org/10.1007/s10961-008 9083-1

41. Sooryamoorthy R. Collaboration and publication: How collaborative are scientists in South Africa? Scientometrics. 2009;80:419-439. http://dx.doi. org/10.1007/s11192-008-2074-z

42. Georghiou L. Global cooperation in research. Res Pol. 1998;27:611-626. http://dx.doi.org/10.1016/S0048-7333(98)00054-7

43. Valderrama Zurian JC, Gonzalez Alcaide G, Valderrama Zurian FJ Aleixandre-Benavent R, Miguel Dasit A. [Co-authorship networks and institutional collaboration in Revista Española de Cardiología]. Rev Esp Cardiol. 2007;60:117-130. Spanish. PMid:17338877

44. Barabasi AL, Albert R. Emergence of scaling in random networks. Science. 1999:286:509-511. http:/ / dx.doi.org/10.1126/science.286.5439.50Wagner CS, Leydesdorff, L. Network structure, self-organization, and the growth CS, Leydesdorff, L. Network structure, self-organization, and the growth of international collaboration in science. Res
http://dx.doi.org/10.1016/j.respol.2005.08.002

45. Wagner CS, Leydesdorff, L. Network structure, self-organization, and the growth of international collaboration in science. Res Pol. 2005;34:16081618. http:/ /dx.doi.org/10.1016/j.respol.2005.08.002

46. Figg WD, Duna L, Liewehr DJ, et al. Scientific collaboration results in higher citation rates of published articles. Pharmacotherapy. 2006;26:759767. http://dx.doi.org/10.1592/phco.26.6.759, PMid:16716129

47. Teasley S, Wolinsky S. Scientific collaborations at a distance. Science. 2001;292:2254-2255. http://dx.doi.org/10.1126/science.1061619, PMid:11423638

48. Merrill J, Hripcsak G. Using social network analysis within a department of biomedical informatics to induce a discussion of academic communities of practice. J Am Med Inf Assoc. 2008;15:780-782. http:/ / dx.doi.org/10.1197/ jamia.M2717, PMid:18756000, PMCid:2585526

49. Saegusa A. Survey finds deep insularity among Japanese scientists. Nature. 1999;401:314. http://dx.doi.org/10.1038/43740

50. Cusmano L, Morrison A, Rabellotti R. Catching up trajectories in the wine sector: A comparative study of Chile, Italy, and South Africa. World Dev. 2010;38(11):1588-1602. http://dx.doi.org/10.1016/j.worlddev.2010.05.002 